\title{
Weed Studies and Productivity of Wheat under Various Planting Techniques and Weed Management Practices
}

\author{
Sudesh Devi", Jagdev Singh, Navish Kumar Kamboj and Virender Singh Hooda \\ Department of Agronomy, Chaudhary Charan Singh Haryana Agricultural University, \\ Hisar- 125004, Haryana, India \\ *Corresponding author
}

\section{A B S T R A C T}

An experiment was conducted in Rabi season of 2012-13 to evaluate the effect of planting techniques and herbicides on weed management and productivity of wheat. Experiment was laid out in a split-plot design, comprising five planting techniques in main-plots, viz. drill sowing at 20,18 and $16 \mathrm{~cm}$, bed planting with three and two rows; and five weed

\section{Keywords}

Herbicide, Nutrients, Planting techniques, Weeds, Wheat.

Article Info

Accepted:

26 October 2017

Available Online:

10 December 2017 control treatments viz. pinoxaden $50 \mathrm{~g} / \mathrm{ha}$ (gram/hectare), RM (ready mix) of carfentrazone + metsulfuron $25 \mathrm{~g} / \mathrm{ha}$, pinoxaden $50 \mathrm{~g} / \mathrm{ha}$ with RM of carfentrazone + metsulfuron 25 $\mathrm{g} / \mathrm{ha}$, weed free and weedy check in subplot with three replications. The weed density of major weeds, total weed dry matter and nutrient uptake by weeds was significantly lower under drill sowing at $16 \mathrm{~cm}$ row of wheat as compared to other planting techniques. Drill sowing at $18 \mathrm{~cm}$ row spacing recorded significantly higher CGR (crop growth rate), grain, biological \& protein yields, and nutrient uptake in grain and straw of wheat, which was statistically at par with drill sowing at $20 \mathrm{~cm}$ row spacing and bed planting with three rows. Tank mix application of pinoxaden $(50 \mathrm{~g} / \mathrm{ha})$ and ready $\mathrm{mix}$ of carfentrazone + metsulfuron ( $25 \mathrm{~g} / \mathrm{ha})$ at 35 days after sowing was found to be effective (with weed control efficiency of 95 percent) against both type of weeds (broad leafed and grassy) with significantly lower value of weed density, weed dry matter and nutrient uptake by weed; and significantly higher value of CGR (crop growth rate), grain, biological \& protein yield and nutrient uptake in wheat (grain+straw) compared to other herbicide treatments. Based on this study, $18 \mathrm{~cm}$ row spacing was found to be optimal (to enhance productivity), and tank mix application of pinoxaden $(50 \mathrm{~g} / \mathrm{ha})+\mathrm{RM}$ of carfentrazone and metsulfuron (25 $\mathrm{g} / \mathrm{ha}$ ) to reduce losses due to complex weed flora in wheat.

\section{Introduction}

In India, wheat (Triticum aestivum L.) is the second most cultivated staple food crop after rice with a grown area of 30.96 million ha, a production of 88.93 million ton and average productivity of $2872 \mathrm{~kg} / \mathrm{ha}$ in 2015-16 (Agricultural Statistics at a glance, 2016). Due to rising demographic pressure, it become necessary to augment the productivity of food crops including wheat on continues basis to ensure food security (Swaminathan and Bhavani, 2013).

Several grassy and broad leaved weeds infest wheat causing severe competition for sunlight, essential nutrients, moisture and space which leads reduction in wheat yield and also its quality (Chhokar et al., 2012; Chopra et al., 2015). Uncontrolled growth of 
weeds on an average caused about 48 per cent reduction in grain yield of wheat when compared with weed-free conditions (Singh et al., 2012).

Among various weeds control strategies such as crop rotations, mechanical practices, hand weeding, herbicide use etc., herbicides are widely used by farmers due to their cost and time effectiveness. Selective herbicides are very effective in controlling weeds in crop, however, continuous use of same herbicide or herbicide having similar mode of action results in weed flora shifts and evolution of resistance in weeds (Yadav et al., 2016). For example, up to 1990s, Phalaris minor was effectively controlled by isoproturon, but due to continuous and indiscriminate use of this herbicide, resistance in $P$. minor evolved against this herbicide in early 1990s (Malik and Singh 1993; Walia et al., 1997). Therefore, alternate herbicides were needed so as to tackle the shift in weed flora and weed resistance problems (Yadav et al., 2016).

Optimal row spacing is one of several important agronomic approaches that can be used to enhance wheat yield (Thorsted et al., 2006; Hussain et al., 2013). Inefficient utilization of available resources by plants, particularly severe inter-row competition among plants in narrow rows and inefficient utilization of natural resources such as light, water, nutrients etc. under wider row spacing have compelled researchers to find optimal row spacing for attaining maximum yield for wheat (Hussain et al., 2013).

Raised bed cultivation offers the potential to reduce water-logging stress through improved surface drainage, and the opportunity to diversify into water logging sensitive crops. Other benefits of raised bed cultivation are reduced tillage costs, improved soil structure and nutrient status from a reduction in oxidation of soil organic matter and disruption of biopores during tillage (Ghane et al., 2011; Dey et al., 2015; Gul et al., 2015)

Keeping these problems in view, a field experiment was conducted to study the effects of various planting techniques and herbicide mixtures on weed management and yield of wheat.

\section{Materials and Methods}

At Agronomy Research Farm of CCS Haryana Agricultural University, Hisar, an experiment was conducted during winter season of 2012-13 in sandy loam soil having $\mathrm{pH}$ 8.3. The soil was low in organic carbon $(0.33 \%)$ and available nitrogen $(182.4 \mathrm{~kg} / \mathrm{ha})$, medium in available phosphorus $(13.3 \mathrm{~kg} / \mathrm{ha})$ and high in available potassium $(365.3 \mathrm{~kg} / \mathrm{ha})$. The experiment was laid out in a split-plot design, comprising five planting techniques in main-plots, viz. drill sowing at $20 \mathrm{~cm}$ (T1), 18 $\mathrm{cm}$ (T2) and $16 \mathrm{~cm}$ (T3), bed planting with three rows (T4) and two rows (T5) and five weed control treatments viz. pinoxaden 50 $\mathrm{g} / \mathrm{ha}$ (C1), RM of carfentrazone + metsulfuron $25 \mathrm{~g} / \mathrm{ha}$ (C2), pinoxaden $50 \mathrm{~g} / \mathrm{ha}$ with $\mathrm{RM}$ of carfentrazone + metsulfuron $25 \mathrm{~g} / \mathrm{ha}$ (C3), weed free (C4) and weedy check (C5) in subplot with three replications. Wheat $c v$ 'WH 711' was sown on $10^{\text {th }}$ December, 2012 with tractor drawn seeding drills using $125 \mathrm{~kg}$ seed rate. Recommended doses of nitrogen $(\mathrm{N})$ and phosphorus $(\mathrm{P})$ were applied through urea and diammonium phosphate (DAP), respectively. Full dose of $\mathrm{P}$ and half dose of $\mathrm{N}$ were applied at sowing time and remaining $\mathrm{N}$ was applied with first irrigation. Herbicides were applied as post-emergence at 35 days after sowing (DAS), with the help of knapsack sprayer fitted with flat-fan nozzle using 500 liter of water/ha under moist field condition. The population and dry matter accumulation of weeds were recorded with quadrates measuring $0.25 \mathrm{~m}^{2}$ area randomly at 
three places in each plot. The data on weeds density were subjected to square-root transformation before statistical analysis. NPK contents in weed and wheat sample were determined by Nessler's reagent method (Linder, 1944), Vanadomolybdo-phosphoric acid yellow-colour (Jackson, 1973) and Flame-photometer methods (Richards, 1954), respectively. The percentage content was multiplied by the total weed dry matter in case of weeds and by grain and straw yields in case of wheat produced for estimation of nutrient uptake ( $\mathrm{kg} / \mathrm{ha})$.

\section{Results and Discussion}

\section{Weed density (No./m²)}

The experimental field was infested with many weeds like Phalaris minor, C. album, M. indicus, Avena ludoviciana, Anagallis arvensis, Coronopus didymus, Lathyrus aphaca, Cirsium arvense, Medicago denticulata, Medicago hispida, Fumeria parviflora, Cynodon dactylon, Vicia sativa and Trifolium fragiferum. Phalaris minor, $C$. album and $M$. indicus were the major weed species and the data on these weeds was analyzed for weed density individually (Table $1)$.

At 30 DAS (Before herbicide spray), different planting techniques had no significant effect on population of $P$. minor, $C$. album and $M$. indicus in wheat (Table 1). This was mainly due to the fact that at initial stage, crop canopy development was almost similar under all planting techniques, as adequate space was available between the rows for weed growth. At 60 DAS (After herbicide spray), lower weed density of all major weeds ( $P$. minor, $C$. album and $M$. indicus) was recorded under drill sowing at $16 \mathrm{~cm}$ row spacing and higher under bed planting with two rows of wheat as compared to other planting techniques (Table 1). The higher weed density under two row bed planting was on account of more space availability in furrows as well as on beds, whereas, less available spaces in narrow row spacing $(16 \mathrm{~cm})$ account for more competition for resources and hence less weed population. Jat et al., (2003) also reported lower weed population under narrow row spacing as compared to wide row spacing.

Weed density of $P$. minor After Herbicide Spray was significantly reduced as compared to weed density Before Herbicide Spray in case of individual application of pinoxaden $(50 \mathrm{~g} / \mathrm{ha})$, whereas RM of carfentrazone + metsulfuron (25 g/ha) significantly reduced the population of $C$. album and $M$. indicus (Table 1). However, weed density of $P$. minor was not show significant change by application of RM of carfentrazone + metsulfuron (25 g/ha) and that of C. album and $M$. indicus by individual application of pinoxaden (50 g/ha) (Table 1). Tank mix application of pinoxaden $(50 \mathrm{~g} / \mathrm{ha})$ with $\mathrm{RM}$ of carfentrazone + metsulfuron $(25 \mathrm{~g} / \mathrm{ha})$ significantly reduced the weed density of all major weeds. Singh et al., (2011) also reported that premix of carfentrazone + metsulfuron@25 g/ha + 0.2\% surfactant provided effective control of broad leaved weeds like $M$. parviflora, L. aphaca, $C$. arvensis, $R$. dentatus, $M$. indica, $M$. denticulata, $A$. arvensis, $C$. didymus and $C$. album. On other side, Hofer et al., (2006) reported that post-emergence application of pinoxaden (30-60 g/ha) was active against a wide range of grassy weed species. Tank mix application of pinoxaden $(50 \mathrm{~g} / \mathrm{ha})$ with $\mathrm{RM}$ of carfentrazone + metsulfuron $(25 \mathrm{~g} / \mathrm{ha})$ significantly reduced the weed density of all major weeds.

\section{Total weed dry matter}

Total weed dry matter accumulation at harvest, was significantly higher under bed planting with two rows of wheat and lower 
under drill sowing with $16 \mathrm{~cm}$ row spacing as compared to other planting techniques (Table 1). Drill sowing with 18 and $20 \mathrm{~cm}$ row spacings was at par with each other in respect to total weed dry matter (Table 1). Conventional planting (flat sowing) techniques (16, 18 and $20 \mathrm{~cm})$ recorded significantly lower weed dry matter as compared to bed planting techniques ( 2 and 3 row) (Table 1). In bed planting techniques, total weed dry matter was recorded significantly lower under three row bed planting over two row bed planting. Highest value of total weed dry matter accumulation under bed planting with two rows was on account of higher weed density as compared other planting techniques. Narrow spacing (16 $\mathrm{cm}$ row spacing) provided minimum space for weeds to grow; thereby resulting in increased competitive potential of crop and hence lowest total weed dry matter accumulation. Walia et al., (2003) reported lesser dry matter accumulation under drill sowing with narrow row spacing in comparison to other planting methods like bed planting with two and three rows and flat sowing with wider spacing. The tank mix application of pinoxaden $(50 \mathrm{~g} / \mathrm{ha})$ with RM of carfentrazone + metsulfuron $(25$ $\mathrm{g} / \mathrm{ha}$ ) resulted in significantly lower total weed dry matter accumulation in comparison to other herbicide treatments due to lower weed infestation and better weed control. Sheoran et al., (2013) reported in wheat crop that pinoxaden tank mixing with broad leaved controlling herbicides are very effective in reducing weed density and dry weight accumulation of weeds.

\section{Weed control efficiency}

Among all planting techniques, highest weed control efficiency was recorded for drill sowing with $16 \mathrm{~cm}$ row spacing and lowest for two row bed planting (Table 1). Among conventional planting techniques, it was observed that the value of weed control efficiency is decreasing as the spacing between rows is increasing (from $16 \mathrm{~cm}$ to 20 $\mathrm{cm})$. Three row bed planting recorded significantly higher value of weed control efficiency over two row bed planting (Table $1)$.

The tank mix application of pinoxaden (50 $\mathrm{g} / \mathrm{ha}$ ) with RM of carfentrazone + metsulfuron $(25 \mathrm{~g} / \mathrm{ha})$ resulted in significantly higher weed control efficiency of $95 \%$ over alone application of pinoxaden (50 g/ha) with RM of carfentrazone + metsulfuron $(25 \mathrm{~g} / \mathrm{ha})$ (Table 1). Pinoxaden showed lower weed control efficiency than other herbicide treatments as experimental field was infested by broad leaved weeds as compared to grassy weeds and pinoxaden (50 g/ha) was more effective in controlling grassy weeds only. Sheoran et al., (2013) reported that pinoxaden tank mixing with broad leaved controlling herbicides gave 85-100\% control of broad leaved weeds and $100 \%$ control of $P$. minor in wheat.

\section{Nutrient uptake by weeds}

Weeds recorded significantly lower NPK uptake under drill sowing with $16 \mathrm{~cm}$ row spacing. Significantly higher uptake of NPK was recorded under bed planting with two rows of wheat followed by bed planting with three rows of wheat (Table 1). NPK uptake by weeds under drill sowing at 18 and $20 \mathrm{~cm}$ row spacing was statistically at par with each other. This variation in NPK uptake with different planting techniques by weeds was mainly on account of varying dry matter accumulation by weeds (Table 1); higher the dry matter, higher will be nutrient uptake as is the case under bed planting with two rows. Significantly lower nutrient (NPK) uptake by weeds under narrow spacing $(16 \mathrm{~cm})$ was mainly on account of lower weed dry matter accumulation by weeds and due to better ground coverage by the crop canopy. 
Table.1 Effect of planting techniques and herbicides on population density (No./ $\mathrm{m}^{2}$ ) of major weeds, total weed dry matter, WCE and weed NPK uptake in wheat

\begin{tabular}{|c|c|c|c|c|c|c|c|c|c|c|c|}
\hline \multirow[t]{2}{*}{ Treatments } & \multicolumn{2}{|c|}{ P. minor $\left(\mathrm{No} . / \mathrm{m}^{2}\right)$} & \multicolumn{2}{|c|}{ C. album (No./m²) } & \multicolumn{2}{|c|}{ M. indicus $\left(\mathrm{No} . / \mathrm{m}^{2}\right)$} & \multirow{2}{*}{$\begin{array}{c}\text { Total } \\
\text { weed } \\
\text { dry } \\
\text { matter*** } \\
\left(\mathbf{g} / \mathbf{m}^{2}\right) \\
\end{array}$} & \multirow{2}{*}{$\begin{array}{c}\text { WCE } \\
(\%)\end{array}$} & \multicolumn{3}{|c|}{ Weeds NPK Uptake } \\
\hline & $\begin{array}{c}\text { BHS* } \\
(30 \\
\text { DAS })\end{array}$ & $\begin{array}{c}\text { AHS } * * \\
(60 \\
\text { DAS })\end{array}$ & $\begin{array}{c}\text { BHS } \\
(\mathbf{3 0} \\
\text { DAS })\end{array}$ & $\begin{array}{c}\text { AHS } \\
(60 \\
\text { DAS })\end{array}$ & $\begin{array}{c}\text { BHS } \\
(\mathbf{3 0} \\
\text { DAS })\end{array}$ & $\begin{array}{c}\text { AHS } \\
(60 \\
\text { DAS })\end{array}$ & & & $\begin{array}{c}\text { N } \\
\text { Uptake } \\
\text { (kg/ha) }\end{array}$ & $\begin{array}{c}\text { P } \\
\text { Uptake } \\
\text { (kg/ha) }\end{array}$ & $\begin{array}{c}\text { K } \\
\text { Uptake } \\
\text { (kg/ha) }\end{array}$ \\
\hline \multicolumn{12}{|c|}{ Planting techniques } \\
\hline $\mathrm{T} 1$ & $3.2(10.2)$ & $2.3(5.4)$ & $4.1(18.3)$ & $2.8(9.7)$ & $4.8(25.7)$ & $3.0(12.8)$ & 59.83 & 60.45 & 8.32 & 2.31 & 6.42 \\
\hline $\mathrm{T} 2$ & $3.1(9.6)$ & $2.3(5.4)$ & $4.1(17.8)$ & $2.7(9.0)$ & $4.8(25.1)$ & $3.0(12.4)$ & 59.07 & 60.72 & 8.28 & 2.28 & 6.37 \\
\hline $\mathrm{T} 3$ & $3.1(10.0)$ & $2.1(4.3)$ & $4.1(18.2)$ & $2.6(7.9)$ & $4.8(25.5)$ & $2.8(10.6)$ & 48.84 & 62.66 & 6.64 & 1.82 & 5.10 \\
\hline $\mathrm{T} 4$ & $3.1(9.7)$ & $2.3(5.8)$ & $4.1(18.1)$ & $2.8(10.6)$ & $4.8(25.3)$ & $3.2(13.7)$ & 62.44 & 60.23 & 8.72 & 2.42 & 6.70 \\
\hline T5 & $3.2(10.2)$ & $2.5(7.1)$ & $4.1(18.2)$ & $3.2(13.8)$ & $4.8(25.8)$ & $3.2(14.7)$ & 67.57 & 59.85 & 9.52 & 2.62 & 7.36 \\
\hline SEm \pm & 0.03 & 0.06 & 0.2 & 0.04 & 0.02 & 0.02 & 0.06 & 0.03 & 0.12 & 0.03 & 0.08 \\
\hline $\mathrm{CD}$ at $5 \%$ & NS & 0.19 & NS & 0.14 & NS & 0.08 & 0.19 & 0.11 & 0.33 & 0.09 & 0.23 \\
\hline \multicolumn{12}{|c|}{ Weed control treatments } \\
\hline $\mathrm{C} 1$ & $3.7(12.5)$ & $1.6(1.8)$ & $4.9(22.5)$ & $5.0(23.5)$ & $5.7(31.7)$ & $5.6(30.8)$ & 120.30 & 20.94 & 14.53 & 3.98 & 11.17 \\
\hline $\mathrm{C} 2$ & $3.6(12.1)$ & $3.6(12.3)$ & $4.9(22.5)$ & $1.7(1.90)$ & $5.7(31.7)$ & $1.5(1.3)$ & 18.29 & 87.97 & 2.06 & 0.58 & 1.60 \\
\hline $\mathrm{C} 3$ & $3.7(12.5)$ & $1.6(1.6)$ & $4.9(22.7)$ & $1.5(1.4)$ & $5.7(32.0)$ & $1.5(1.2)$ & 7.60 & 95.00 & 0.87 & 0.30 & 0.66 \\
\hline $\mathrm{C} 4$ & $1.0(0)$ & $1.0(0)$ & $1.0(0)$ & $1.0(0)$ & $1.0(0)$ & $1.0(0)$ & 0.00 & 100.00 & 0.00 & 0.00 & 0.00 \\
\hline $\mathrm{C} 5$ & $3.7(12.6)$ & $3.6(12.4)$ & $4.9(22.8)$ & $5.0(24.3)$ & $5.7(32.0)$ & $5.6(30.8)$ & 151.56 & 0.00 & 15.72 & 4.37 & 12.12 \\
\hline SEm \pm & 0.05 & 0.10 & 0.04 & 0.10 & 0.04 & 0.12 & 0.05 & 0.03 & 0.10 & 0.03 & 0.07 \\
\hline $\mathrm{CD}$ at $5 \%$ & 0.15 & 0.28 & 0.12 & 0.30 & 0.10 & 0.35 & 0.13 & 0.08 & 0.34 & 0.09 & 0.24 \\
\hline
\end{tabular}

Data in parenthesis was subjected to square root $(\sqrt{x+1})$ transformation before analysis. * BHS - Before herbicide spray (at 30 DAS); **AHS - Before herbicide spray (at $60 \mathrm{DAS}$ ); ***Total weed dry matter include both grassy and broad leaved weed dry matter. WCE- weed control efficiency, N-nitrogen, Pphosphorus, K-potassium. 
Table.2 Effect of planting techniques and herbicides on CGR, grain and biological yields, HI and quality parameters of wheat

\begin{tabular}{|c|c|c|c|c|c|c|c|c|c|c|c|c|}
\hline \multirow[t]{2}{*}{ Treatments } & \multicolumn{4}{|c|}{ Crop growth rate $\left(\mathrm{g} / \mathrm{m}^{2} / \mathrm{day}\right)$} & \multirow{2}{*}{$\begin{array}{l}\text { Grain } \\
\text { Yield } \\
\text { (t/ha) }\end{array}$} & \multirow{2}{*}{$\begin{array}{c}\text { Biological } \\
\text { yield } \\
\text { (t/ha) }\end{array}$} & \multirow{2}{*}{$\begin{array}{c}\text { Harvest } \\
\text { Index } \\
(\%)\end{array}$} & \multirow{2}{*}{$\begin{array}{c}\text { Sedimentation } \\
\text { value }\end{array}$} & \multirow{2}{*}{$\begin{array}{c}\text { Protein } \\
\text { content } \\
(\%)\end{array}$} & \multirow{2}{*}{$\begin{array}{c}\text { Protein } \\
\text { yield } \\
\text { (kg/ha) }\end{array}$} & \multirow{2}{*}{$\begin{array}{c}\text { Starch } \\
\text { content } \\
(\%)\end{array}$} & \multirow{2}{*}{$\begin{array}{c}\text { Grain } \\
\text { appearance }\end{array}$} \\
\hline & $\begin{array}{c}60 \\
\text { DAS } \\
\end{array}$ & $\begin{array}{c}90 \\
\text { DAS } \\
\end{array}$ & $\begin{array}{l}\text { 120 } \\
\text { DAS }\end{array}$ & $\begin{array}{c}\text { At } \\
\text { harvest }\end{array}$ & & & & & & & & \\
\hline \multicolumn{13}{|c|}{ Planting techniques } \\
\hline T1 & 5.05 & 17.18 & 18.37 & 7.14 & 5.20 & 13.32 & 39.0 & 34.20 & 12.62 & 657.14 & 61.28 & 6.27 \\
\hline $\mathrm{T} 2$ & 5.06 & 17.21 & 18.43 & 7.58 & 5.33 & 13.56 & 39.3 & 35.33 & 12.45 & 664.46 & 61.28 & 6.39 \\
\hline $\mathrm{T} 3$ & 4.73 & 15.93 & 17.07 & 6.36 & 4.94 & 12.74 & 38.7 & 33.93 & 12.20 & 602.78 & 61.29 & 6.19 \\
\hline $\mathrm{T} 4$ & 4.95 & 16.96 & 18.33 & 6.65 & 5.20 & 13.19 & 39.3 & 34.73 & 12.64 & 657.23 & 61.28 & 6.13 \\
\hline T5 & 4.91 & 16.68 & 17.48 & 7.14 & 4.85 & 12.65 & 38.4 & 34.27 & 12.25 & 595.73 & 61.30 & 5.93 \\
\hline SEm \pm & 0.01 & 0.02 & 0.41 & 0.46 & 0.07 & 0.12 & 0.60 & 0.59 & 0.24 & 19.61 & 0.03 & 0.13 \\
\hline $\mathrm{CD}$ at $5 \%$ & 0.01 & 0.85 & $\mathrm{NS}$ & NS & 0.24 & 0.39 & $\mathrm{NS}$ & $\mathrm{NS}$ & $\mathrm{NS}$ & 46.73 & $\mathrm{NS}$ & $\mathrm{NS}$ \\
\hline \multicolumn{13}{|c|}{ Weed control treatments } \\
\hline $\mathrm{C} 1$ & 4.85 & 16.35 & 17.94 & 6.21 & 5.04 & 13.12 & 38.4 & 34.27 & 12.43 & 627.00 & 61.29 & 6.13 \\
\hline $\mathrm{C} 2$ & 4.90 & 16.64 & 17.75 & 6.92 & 5.19 & 13.17 & 39.4 & 34.40 & 12.45 & 647.12 & 61.28 & 6.18 \\
\hline $\mathrm{C} 3$ & 5.05 & 17.44 & 18.49 & 7.20 & 5.32 & 13.47 & 39.5 & 35.73 & 12.50 & 665.22 & 62.29 & 6.29 \\
\hline $\mathrm{C} 4$ & 5.26 & 17.86 & 19.01 & 7.35 & 5.47 & 13.78 & 39.7 & 36.53 & 12.64 & 691.19 & 62.29 & 6.31 \\
\hline $\mathrm{C} 5$ & 4.63 & 15.68 & 16.50 & 7.18 & 4.51 & 11.92 & 37.8 & 31.53 & 12.14 & 546.81 & 61.27 & 6.00 \\
\hline SEm \pm & 0.002 & 0.01 & 0.35 & 0.39 & 0.07 & 0.11 & 0.50 & 0.50 & 0.15 & 11.38 & 0.04 & 0.03 \\
\hline $\mathrm{CD}$ at $5 \%$ & 0.01 & 0.26 & NS & NS & 0.19 & 0.31 & $\mathrm{NS}$ & 1.42 & $\mathrm{NS}$ & 32.55 & $\mathrm{NS}$ & 0.08 \\
\hline
\end{tabular}

Table.3 Effect of planting techniques and herbicides on NPK content and uptake in wheat

\begin{tabular}{|c|c|c|c|c|c|c|c|c|c|c|c|c|}
\hline \multirow[t]{2}{*}{ Treatments } & \multicolumn{2}{|c|}{$\mathrm{N}$ content $(\%)$} & \multicolumn{2}{|c|}{$N$ uptake $(\mathrm{kg} / \mathrm{ha})$} & \multicolumn{2}{|c|}{$P$ content $(\%)$} & \multicolumn{2}{|c|}{ P uptake (kg/ha) } & \multicolumn{2}{|c|}{ K content $(\%)$} & \multicolumn{2}{|c|}{ K uptake (kg/ha) } \\
\hline & Grain & Straw & Grain & Straw & Grain & Straw & Grain & Straw & Grain & Straw & Grain & Straw \\
\hline \multicolumn{13}{|c|}{ Planting techniques } \\
\hline T1 & 2.02 & 0.34 & 105.14 & 27.84 & 0.31 & 0.07 & 16.38 & 5.36 & 0.41 & 1.93 & 21.35 & 156.98 \\
\hline $\mathrm{T} 2$ & 1.99 & 0.35 & 106.31 & 28.96 & 0.33 & 0.07 & 17.38 & 5.44 & 0.42 & 1.93 & 22.40 & 159.22 \\
\hline T3 & 1.95 & 0.33 & 96.44 & 26.11 & 0.33 & 0.07 & 16.20 & 5.24 & 0.41 & 1.94 & 20.26 & 151.35 \\
\hline $\mathrm{T} 4$ & 2.02 & 0.34 & 105.16 & 27.05 & 0.32 & 0.06 & 16.52 & 5.24 & 0.43 & 1.94 & 22.09 & 155.18 \\
\hline T5 & 1.96 & 0.35 & 95.65 & 26.71 & 0.32 & 0.06 & 15.63 & 5.09 & 0.43 & 1.94 & 20.63 & 151.16 \\
\hline SEm \pm & 0.04 & 0.01 & 3.64 & 0.70 & 0.01 & 0.001 & 0.38 & 0.14 & 0.01 & 0.01 & 0.34 & 2.19 \\
\hline $\mathrm{CD}$ at $5 \%$ & NS & NS & 8.58 & 2.77 & NS & NS & 1.24 & NS & NS & NS & 1.11 & 5.19 \\
\hline \multicolumn{13}{|c|}{ Weed control treatments } \\
\hline $\mathrm{C} 1$ & 1.99 & 0.34 & 100.32 & 27.01 & 0.32 & 0.06 & 16.01 & 5.26 & 0.42 & 1.94 & 21.01 & 156.47 \\
\hline $\mathrm{C} 2$ & 1.99 & 0.34 & 103.54 & 26.97 & 0.32 & 0.06 & 16.61 & 5.22 & 0.42 & 1.94 & 21.61 & 154.66 \\
\hline $\mathrm{C} 3$ & 2.00 & 0.35 & 106.77 & 28.87 & 0.33 & 0.07 & 17.32 & 5.39 & 0.42 & 1.94 & 22.33 & 157.92 \\
\hline $\mathrm{C} 4$ & 2.02 & 0.36 & 110.59 & 29.78 & 0.33 & 0.07 & 18.14 & 5.71 & 0.43 & 1.95 & 23.30 & 162.38 \\
\hline $\mathrm{C} 5$ & 1.94 & 0.32 & 87.49 & 24.02 & 0.31 & 0.06 & 14.04 & 4.79 & 0.41 & 1.92 & 18.49 & 142.47 \\
\hline SEm \pm & 0.02 & 0.01 & 1.82 & 0.74 & 0.01 & 0.003 & 0.37 & 0.28 & 0.004 & 0.01 & 0.37 & 1.80 \\
\hline $\mathrm{CD}$ at $5 \%$ & NS & NS & 5.21 & 2.13 & NS & NS & 1.06 & $\mathrm{NS}$ & NS & NS & 1.07 & 5.16 \\
\hline
\end{tabular}


Fig.1 Per cent increase in grain and biological yields by various planting techniques over two rows bed planting

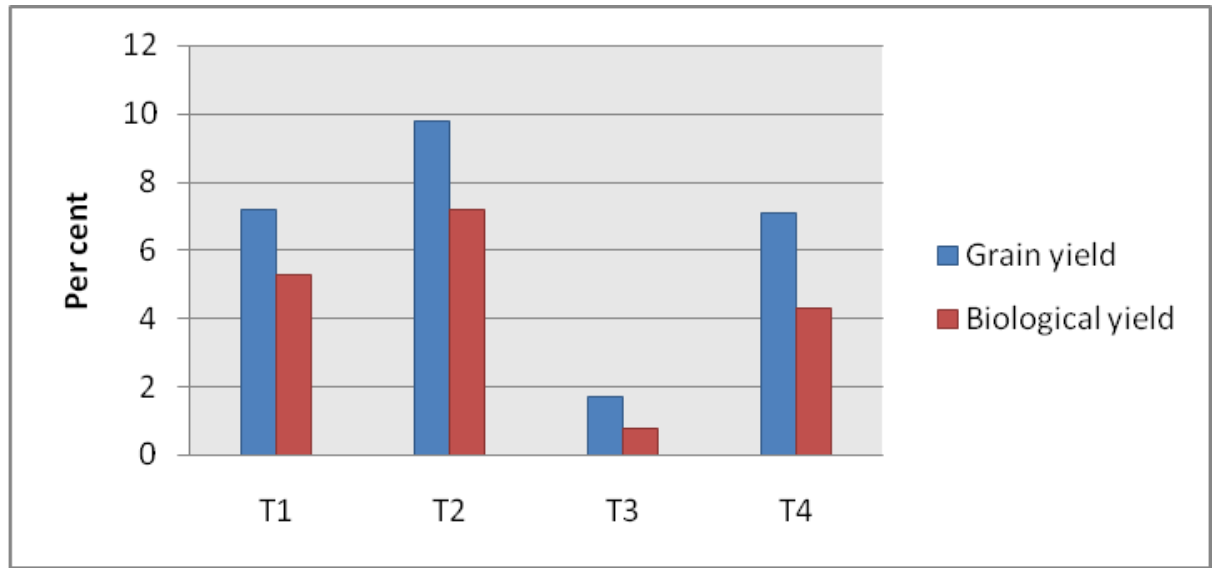

Fig.2 Per cent increase in grain, straw and biological yields by various weed control treatments over weedy check

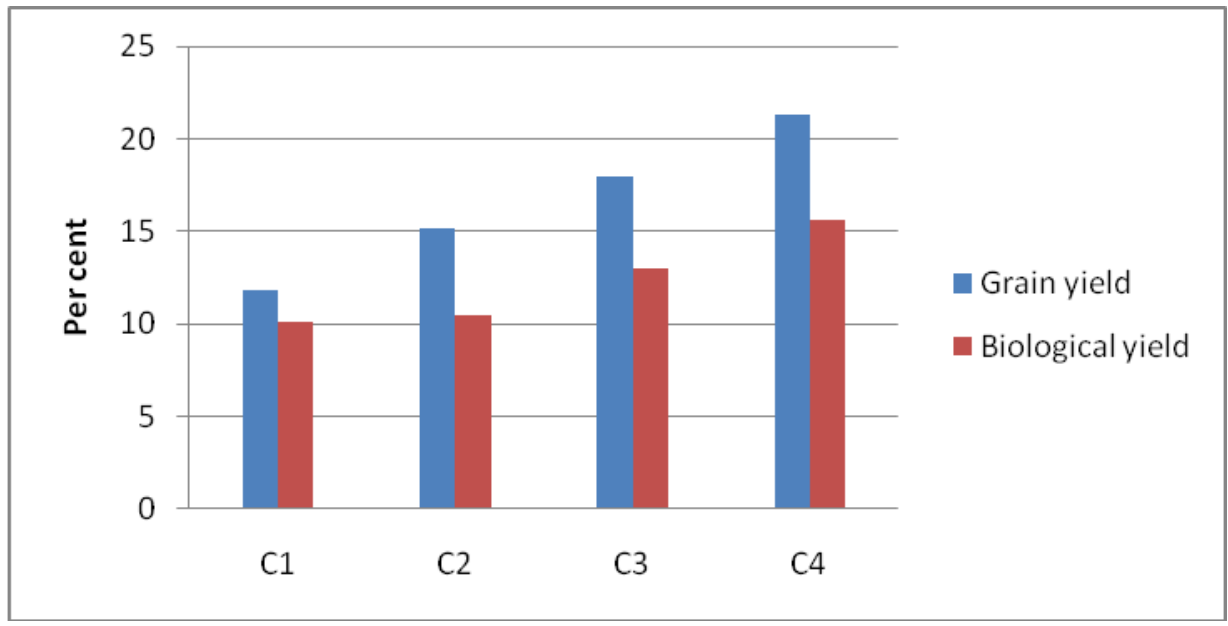

Fig.3 Total NPK uptake (kg/ha) by crop under various planting techniques

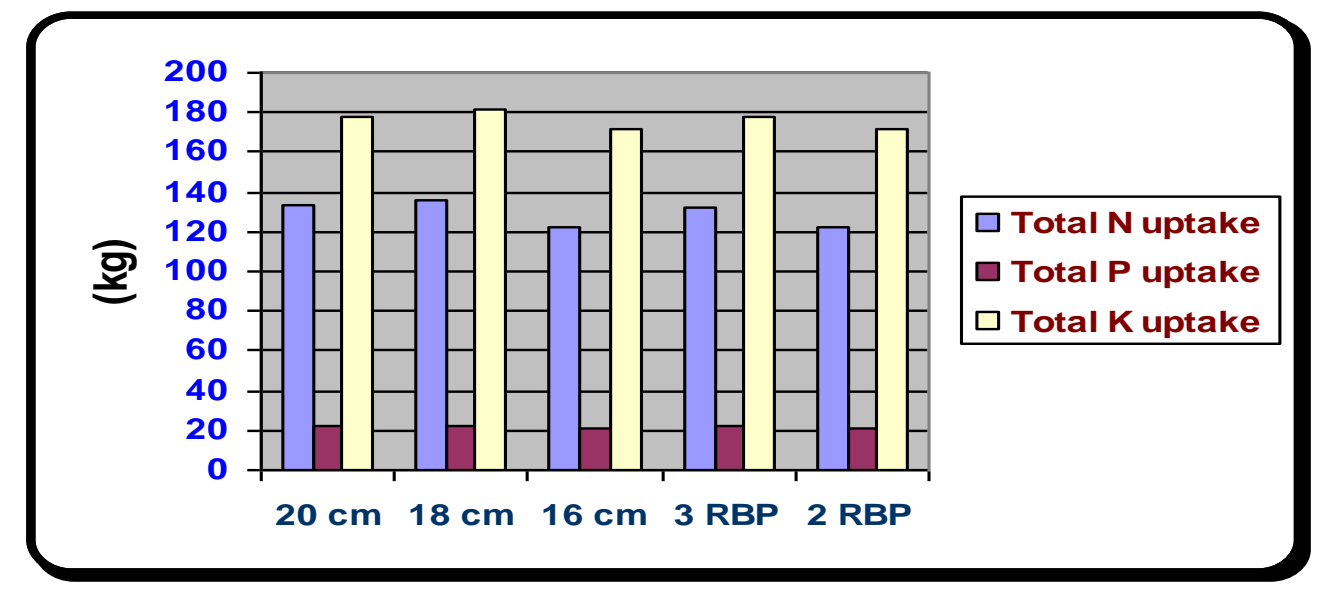


Fig.4 Total NPK uptake (kg/ha) by crop under various weed control treatments

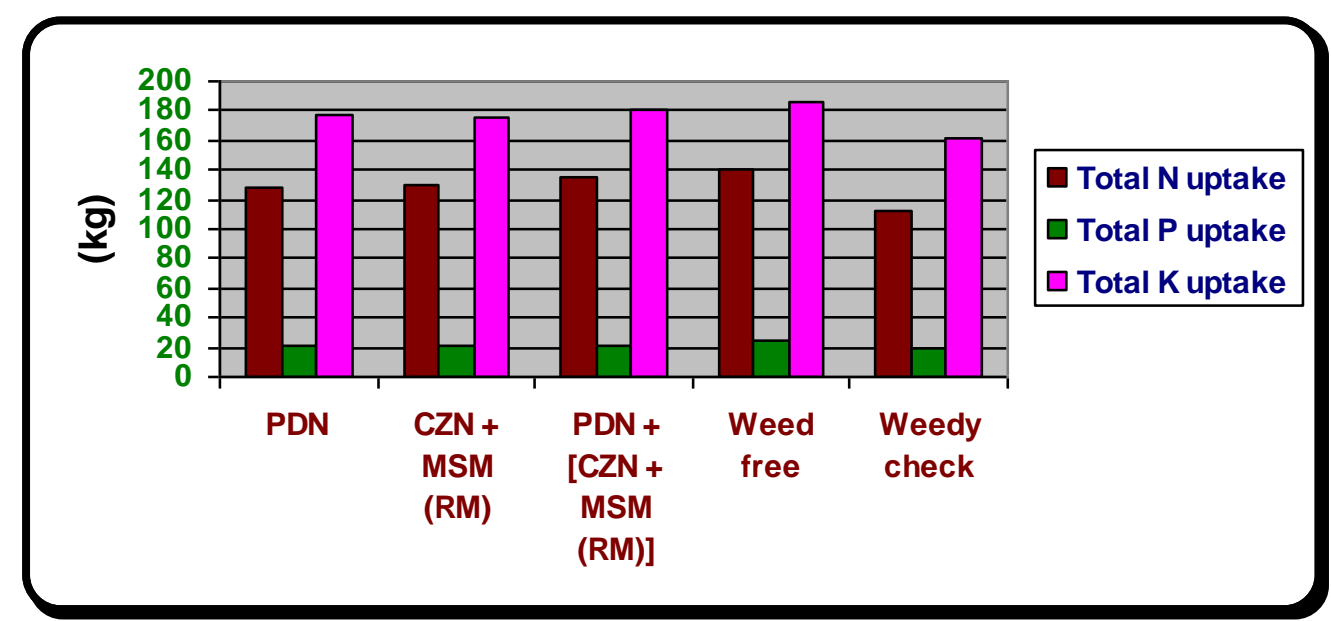

Bhullar and Walia (2003) reported that wheat crop raised with closer row spacing recorded significantly higher uptake of NPK while nutrient depletion by weeds like $P$. minor decreased considerable compared to crop raised with wider row spacing.

Weed control treatments significantly affected the NPK uptake by weeds (Table 1). Lower NPK uptake was recorded under tank mix application of pinoxaden $50 \mathrm{~g} / \mathrm{ha}$ with RM of carfentrazone + metsulfuron $25 \mathrm{~g} / \mathrm{ha}$ due to better control of complex weed flora, as is evident by lesser dry matter accumulation and weed density. Pandey et al., (2001) reported that effective weed control measures increase the uptake of nutrients by crop and decrease their removal by weeds.

\section{Crop growth rate}

Crop growth rate (CGR) of wheat increased with advancement of crop growth and highest increase was recorded between 60 to 90 DAS (Table 2). CGR of wheat was not significantly influenced by planting techniques except at 60 and 90 DAS. At 60 and 90 DAS, significantly higher CGR was recorded under drill sowing with $18 \mathrm{~cm}$ which was at par with $20 \mathrm{~cm}$ row spacing due to more leaf growth, more dry matter accumulated by crop. At 60 and 90 DAS, drill sowing with $16 \mathrm{~cm}$ row spacing observed lowest CGR over other planting techniques. Among bed planting techniques, three row bed planting showed higher crop growth rate over two row bed planting at 60 DAS, however at 90 DAS, CGR was statistically at par with each other at 90 DAS due to more plant per square metre and more dry matter accumulation per metre square. CGR was not significantly influenced by weed control treatments at all crop growth stages except at 60 and 90 DAS. Among herbicide treatments, at 60 and 90 DAS, tank mix application of pinoxaden $50 \mathrm{~g} / \mathrm{ha}$ with $\mathrm{RM}$ of carfentrazone + metsulfuron $25 \mathrm{~g} / \mathrm{ha}$ recorded highest CGR and weedy check recorded lowest CGR due to effective weed control crop get more space for growth and accumulated more dry weight (Table 2).

\section{Grain and biological yield}

The data revealed that among different planting techniques, drill sowing at $18 \mathrm{~cm}$ row spacing in wheat recorded maximum grain and biological yield, which was statistically at par with the sowing at $20 \mathrm{~cm}$ row spacing and bed planting with three rows of wheat (Table 2). Lowest grain and 
biological yield was recorded under two rows bed planting which is at statistically par with $16 \mathrm{~cm}$ row spacing due to low plant population and over plant population, respectively. The percentage increase in grain yield and biological yield for different planting techniques over two row bed planning has been shown in figure 1. Abbas et al., (2009) found that grain yield of wheat was higher in wider row spacing than narrow row spacing $(15 \mathrm{~cm})$.

Weed free treatment registered maximum grain and biological yield (5.47 t/ha), which was at par with tank mix application of pinoxaden (50 $\mathrm{g} / \mathrm{ha})$ with $\mathrm{RM}$ of carfentrazone + metsulfuron $(25 \mathrm{~g} / \mathrm{ha})$ (Table 2). Grain and biological yields under individual application of pinoxaden $(50 \mathrm{~g} / \mathrm{ha})$ and RM of carfentrazone + metsulfuron $(25$ $\mathrm{g} / \mathrm{ha}$ ) were at par with each other. The per cent increase in grain yield with the application of pinoxaden (50 g/ha), RM of carfentrazone + metsulfuron, tank mix of pinoxaden (50 $\mathrm{g} / \mathrm{ha})$ with $\mathrm{RM}$ of (carfentrazone + metsulfuron) and weed free treatments over weedy check is shown in figure 2. Chopra et al., (2008) reported in experiment that herbicide mixture like fenoxaprop-p-ethyl + carfentrazone recorded highest grain yield which was as par with weed free treatment.

\section{Quality parameters}

Different planting techniques did not show any significant variation on quality parameters viz. sedimentation value, protein content, starch content and grain appearance (Table 2). Similarly, Kumar (2001) reported that protein content did not differ significantly between two planting systems in wheat. Drill sowing at 18 and $20 \mathrm{~cm}$ row spacing and bed planting with three rows were at par in respect of protein yield (Table 2) and significantly superior to $16 \mathrm{~cm}$ and two row bed planting method. As the protein content in grains did not show any appreciable variation with different planting techniques, the higher protein yield in $18 \mathrm{~cm}, 20 \mathrm{~cm}$ and 3 row bed planting may be attributed to the fact that the protein yield followed the grain yield pattern (Table 1).

Different weed control treatments did not show any variation in respect of protein content and starch content. However, weed free was statistically at par to combined application of pinoxaden $(50 \mathrm{~g} / \mathrm{ha})$ and ready mix of carfentrazone + metsulfuron $(25 \mathrm{~g} / \mathrm{ha})$ herbicides at 35 DAS and have significantly higher values of sedimentation value, grain appearance and protein yield than other weed control treatments (Table 2). This was obviously due to the fact that proper weed control practices improved the growth, yield and ultimately the physical quality of the grain.

\section{Nutrient content and uptake by crop}

The differences in nitrogen $(\mathrm{N})$, phosphorus (P) and potassium $(\mathrm{K})$ content $(\%)$ in wheat grain and straw remained non-significant due to different planting techniques and weed control treatments (Table 3). Drill sowing at 18 and $20 \mathrm{~cm}$ row spacings and bed planting with three rows were at par in respect of $\mathrm{N} \&$ $\mathrm{K}$ uptake both in grain and straw (Table 3) and as well as total uptake (Fig. 3).

Drill sowing at $18 \mathrm{~cm}$ row spacing has significantly higher nitrogen uptake by straw as compared to $16 \mathrm{~cm}$ row spacing and phosphorus uptake by grain in comparison to two row bed planting. As the nutrient contents were not significantly influenced, the higher uptake is mainly attributed to higher grain and straw yield obtained in $18 \mathrm{~cm}, 20 \mathrm{~cm}$ row spacing and three row bed planting method (Table 2). The finding corroborated the results obtained by Kumar (2001). 
Weed free and combined application of both pinoxaden (50 g/ha) and ready mix of carfentrazone + metsulfuron $(25 \mathrm{~g} / \mathrm{ha})$ herbicides at 35 DAS were at par in respect of nitrogen, phosphorus and potassium uptake in grain and straw (Table 3) as well as total uptake (Fig. 4) and significantly has more nutrient uptake except phosphorus uptake by straw which was not significantly influenced by various weed control treatments. The higher nutrient uptake is mainly due to higher grain and straw yields (Table 3 ) obtained in weed free and herbicide mixture treatments on account of better weed control of mixed weed flora. Pandey et al., (2001) reported that effective weed control measure increase the uptake of nutrient by crop than weedy check.

\section{Acknowledgement}

The authors thank to department of Agronomy, CCS HAU, Hisar, for their support for this research.

\section{References}

Abbas, G., Ali, M.A., Abbas, G., Azam, M. and Hussain, I., 2009. Impact of planting methods on wheat grain yield and yield contributing parameters. $J$. Anim. Plant Sci., 19: 30-33.

Agricultural Statistics at a Glance, 2016. Directorate of Economics and Statistics, Ministry of Agriculture, Govt. of India (Website:

http://www.dacnet.nic.in/PDF/Glance2016.pdf).

Bhullar, M.S. and Walia, U.S., 2003. Effect of seed rate, row spacing and herbicides on uptake of nutrient by $P$. minor and wheat. J. Res., 40: 3-4.

Chhokar, R.S., Sharma, R.K. and Sharma, I. 2012. Weed management strategies in wheat-A review. J. Wheat Res., 4: 1-21.

Chopra, N. K., Chopra, N. and Choudhary, D. 2015. Bioefficacy of sole and tank-mix of pinoxaden and clodinafop with carfentrazone and metsulfuron for control of complex weed flora in wheat (Triticum aestivum). Indian J. Agron., 60: 104-108.

Chopra, N.K., Chopra, N. and Singh, H. 2008. Bio-efficacy of herbicide mixtures against complex weed flora in wheat (Triticum aestivum). Indian J. Agron., 53: 62-65.

Dey, D., Nath, D. and Jamatia, P. B. 2015. Effect of raised bed planting method of maize under sandy loam soil of west Tripura. Int. J. Appl., Res.1: 561-563.

Ghane, E., Mostafazadeh-Fard, B., Feizi, M. and Landi, E. 2011. Effect of water quality and different planting methods on wheat yield. Commun. Soil Sci. Plan., 42: 369-380

Gul, S., Khan, M.H., Khanday, B.A. and Nabi, S. 2015. Effect of Sowing Methods and NPK Levels on Growth and Yield of Rainfed Maize (Zea mays L.). Hindawi Publishing Corporation Scientifica

(Website: http://dx.doi.org/10.1155/2015/198575).

Hofer, U., Muehlebach, M., Hole, S. and Zoschke, A. 2006. Pinoxaden - for broad spectrum grass weed management in cereal crops. J. Plant Dis. Protect., Sonderheft XX: 989-995.

Hussain, M., Khan, M.B., Mehmood, Z., Zia, A.B., Jabran, K. and Farooq, M. 2013. Optimizing row spacing in wheat cultivars differing in tillering and stature for higher productivity. Arch. Agron. Soil Sci., 59: 1457-1470.

Jackson, M.L. 1973. Soil chemical analysis. Prentice Hall of India Pvt. Ltd., New Delhi. pp. 214-221.

Jat, R.S., Nepalia, V. and Chaudhary, P.D. 2003. Influence of herbicides and methods of sowing on weed dynamics in wheat (Triticum aestivum L.). Indian J. Weed Sci., 35: 18-20.

Kumar, R. 2001. Effect of planting systems, 
seed rates and nitrogen levels on the wheat productivity (Triticum aestivum L.) $\mathrm{Ph}$. D. Thesis submitted to CCS HAU, Hisar.

Lindner, R.C. 1944. Rapid analytical methods for some of the more common inorganic constituents of plant tissues. Plant Physiol., 19: 76-86.

Malik, R.K. and Singh, S. 1993. Evolving strategies for herbicide use in wheat resistance and integrated weed management. In: Proc. Indian Soc. Weed Sci. Int. Symp. Integrated Weed Management for Sustainable Agriculture, 18- 20 November 1993, pp. 225-238, Hisar, India.

Pandey, I.B., Sharma, S.L., Tiwary, S. and Bharati, V. 2001. Effect of tillage and weed management on grain and nutrient removal by wheat (Triticum aestivum) and weeds. Indian J. Weed Sci., 32: 107-111.

Richards, L.A. 1954. Diagnosis and improvement of saline and alkali soils; USDA Hand Book No. 60, United State Salinity Laboratory.

Shoeran, S., Punia, S.S., Yadav, A. and Singh, S. 2013. Bioefficacy of pinoxaden in combination with other herbicides against complex weed flora in wheat. Indian J. Weed Sci., 45: 90-92.

Singh, R., Singh, P., Singh, V.K., Singh, V.P. and Pratap, T. 2012. Effect of different herbicides on weed dry matter and yield of wheat. Int. Agron. Congr., 2: 138139.

Singh, S., Punia, S.S., Yadav, A. and Hooda, V.S. 2011. Evaluation of carfentrazone ethyl + metsulfuron - methyl against broadleaf weeds of wheat. Indian $J$. Weed Sci., 43: 12-22.

Swaminathan, M.S. and Bhavani R.V. 2013. Food production \& availability Essential prerequisites for sustainable food security. Indian J. Med. Res., 138: 383-391.

Thorsted, M.D., Olesen, J.E. and Weiner, J. 2006. Width of clover strips and wheat rows influence grain yield in winter wheat/white clover intercropping. Field Crop Res., 95: 280-290.

Walia, U.S., Brar, L.S. and Jand, S. 2003. Integrated effect of planting methods and herbicides on Phalaris minor and wheat. Indian J. Weed Sci., 35: 169172.

Yadav, D.B., Yadav, A., Punia, S.S. and Chauhan, B.S. 2016. Management of herbicide-resistant Phalaris minor in wheat by sequential or tank-mix applications of pre- and post-emergence herbicides in north-western IndoGangetic Plains. Crop Prot., 89: 239247.

\section{How to cite this article:}

Sudesh Devi, Jagdev Singh, Navish Kumar Kamboj and Virender Singh Hooda. 2017. Weed Studies and Productivity of Wheat under Various Planting Techniques and Weed Management Practices. Int.J.Curr.Microbiol.App.Sci. 6(12): 3279-3289. doi: https://doi.org/10.20546/ijcmas.2017.612.381 